\title{
Project proposal for the urban redevelopment of Oia, the sunset town
}

\author{
M. Antonelli, C. Crescenzi \& V. Grillo \\ Università degli Studi di Firenze, DIDA, Firenze, Italia
}

\begin{abstract}
Santorini is one of the study sites proposed by the European project Crhima-CINP, (Cultural Rupestrian Heritage in the circum-Mediterranean area. Common Identity, New Perspective) financed by Culture Programme 2007-2013. Its purpose is to enhance the cultural area shared by Europeans, the development of cooperation between the creators, actors and cultural institutions of the countries participating. Unique landscape for wild territory, anthropic action and geographical location; the persistence of troglodytes systems and of vernacular settlement have made it attractive and appealing. Research focused on the small village of Oia. It has a delicate balance; remarkable the anthropic pressure in recent years of tourism, in particular at sunset time. Guests come from the entire island and pour on the sidelines of the streets that climb the caldera. The project contrasts the individualistic logic of land use, preserves social and communitarian use of historic architecture, and proposes the integration of urban places.
\end{abstract}

\section{INTRODUCTION}

Oia, the town of Sunset, is a village in the north of the island of Santorini, lying to the south in the Cyclades archipelago. The unmistakable contemporary face of Santorini island is given by the appearance of its landscape marked by the erosion of wind and the wounds of the earthquake, the geology of colored rock and humane solutions to the particular and contingent local aspects.

Santorini, a place of transit of civilizations and peoples, it is surprising for the extraordinary mingling of the natural and man-made environment: the archetype of the shelter to live in caves, similar for type and equipment to those found in many of the regions of the Mediterranean; the built essence of Mediterranean architecture with vaulted roofs and stone extrados, distinct from habitual architecture of Aegean; archaeological evidence of rich and cultured cities as the Minoan city of Akrotiri, destroyed by the great eruption of $1500 \mathrm{BC}$, which makes possible to identify the island with the mythical Atlantis.

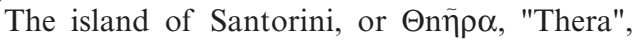
is the largest of the islands in the Aegean Sea. It, together with the island of Thirasia, has a circular shape that closes the central islands of Nea Kameni and Palia Kameni. The island structure is due to the long succession of eruptive and explosive events of the volcano. The caldera, concave part of the island, is consists of steep cliffs, almost vertical, from 100 to 350 meters high. It shows the varied geological and mineralogical composition with a thousand different colours. The east coast of the island is sweeter and form natural beaches of black volcanic sand. The vegetation is low to withstand the strong winds coming from the north and northwest and to the lack of rainwater.

The island's population, approximately 13,701 (2001) inhabitants, lies in thirteen major settlements. The volcanic origin of the island and the geological transformations have defined a unique landscape, tough and hard, that forced the man to realize a vernacular heritage and sustainable. The absolute aesthetic value of the island, exclusive heritage, and its features have to be protected from human logic of profit, from overcrowding of summer tourism, and from neglect for places.

Dry stone walls and terraces, "xerolithies", works to protect the territory and landscape, they preserved water resources of the area and they defended it from erosion by wind and water; the abandon and their loss affects the territory and its liveability, and undermines the very stability of the settlements historicized. The furrows traced by the seasonal water perpendicular to the shoreline have beds steep and wide (NAMA 1998, v.2, 4), are in fact subject to significant wind and water erosion.

\section{SETTLEMENT OF OIA}

The settlement of Oia, Ia or Apano Meria, is located on the headland peninsula and is connected to the rest of the island with only two driveways, one coastal and the other recently excavated in the rock on the rampart of the hill; this is the main artery that connects the village to the town of Fira and at infrastructure nodes such as the port and airport. 


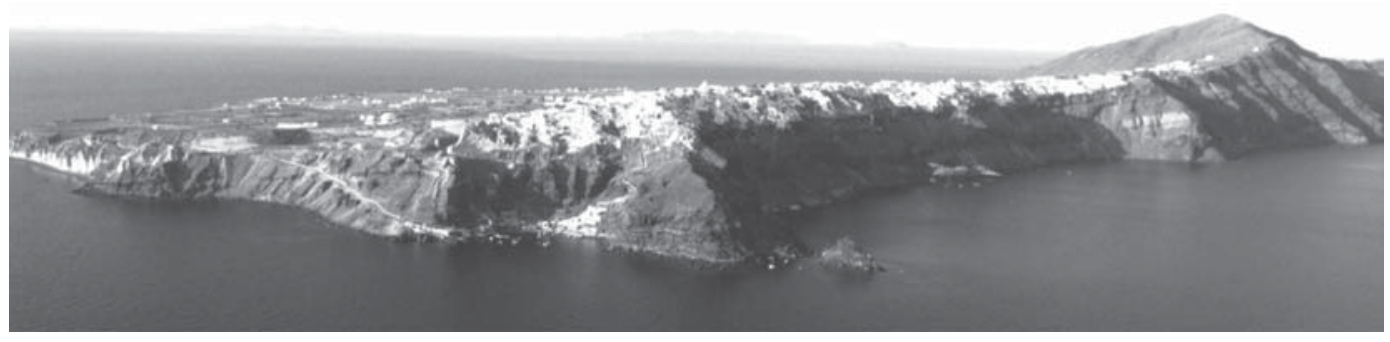

Figure 1. Aerial view of the extreme northern portion of Santorini's island (Municipality of Thera).

The geography of the peninsula is characterized at south by the caldera, on which ridge it develops the settlement, while to the north the land slopes down to the sea constant.

Oia, during the rule of the Franks was one of five fortified "Kastelia" that made up the administration of the island and was ruled by the Venetians. The village prospered from the late ninth century to the early twentieth thanks to the production and marketing of wine and to trade entertained with the Mediterranean countries.

With the diffusion of steam machinery and the movement of investment capital in the port of Piraeus in Athens, there was a gradual economic decline of the thriving port of Oia and a consequent gradual depopulation of the village. Its abandonment caused the degradation of the urban and regional structure. In 1977 we have reached a historic low with 306 residents including 16 dedicated to tourism; in 1991 there was a slight increase, while in 2001 the village reaches 3376 inhabitants, largely devoted to tourism.

The urban structure of the settlements on the island, which have developed over time, are due to the environmental factors, the geographic location dominant in the Aegean Sea, and the tumultuous historical events that have affected the sea and its islands. We distinguish three main groups: fortified settlements that develop along radial directions, those in linear development, and troglodyte settlements, hypogea and excavated.

The agglomeration of Oia consists of 6 villages that exemplify the main settlement types: Ia, the district of Perivolas, the rural areas of Finikia and Tholos and the two coastal resorts of Amoudi and Armeni.

Oia, founded as a fortified settlement, spread outside the walls as an excavated settlement on the rock wall of the caldera. The first documented sources of the settlement of Oia date back to 1480; they describe the seventeenth century fortified village with a population of 500 individuals, who mostly lived in caves. The original settlement was located in the northwest of the present town, it was almost completely destroyed by earthquakes and today remains only the Goulas, the fortified tower of the ancient castle built in red and black volcanic stone typical of the island. The native stone is the most widely used building material, and it provided, over the years, an excellent protection against fire.

The homes had a rupestrian nucleus carved into the rock. It was intended for the storage of food or shelter animals, while the upper floor was used as a dwelling. Narrow outside stairs leading from the street to the upper floors with vaulted spaces barrel.

In 1750 Oia was a densely built settlement and a fortified castel in the northwestern side. The city develops linearly along the caldera and then along the gorges of Finikia, created by the erosive action of seasonal streams.

Along the ridge there are hypogeal homes: from the glacis you descend into a courtyard, fitted of cistern for collecting water, and usually overlooked by a room with a kitchen-oven, a second tank and, in depth, one or more rooms. Above the hypogea, at the beginning of the twentieth century, the houses were built "by the ship-owners." These homes feature neo-classical elements with influences of the Renaissance architectural models reinterpreted with local architectural elements such as arches, vaults, etc. The figurative elements and structural environments are larger than those of traditional houses in the other districts, show the health and wealth of the owners derived from the flourishing trade and their social success.

On the sides of the Caldera have been excavated accommodation "of the crew", vernacular architecture of great plasticity.

Rupestrian buildings characterize the district of Perivolas, inhabited by farmers-winegrowers: the "kanava", ancient and modern carved cellars developed along the path immediately beneath the cultivated land. Perivolas hosts a number of recent buildings built after the earthquake of 1956 . They were the answer to the housing needs of the population and at their desire to stay in the places of origin. The residential units are similar to that designed for Kamari by Greek architect Konstantin Decavalla: a habitation module and replicable 
quickly constructible. The accommodation is a restatement of the vernacular home of the island, is composed of two walls with a roof barrel vault with a semicircular profile and with two small courtyards on both sides of the house. Finikia welcomes the rupestrian settlements in her sidelines; the main road infrastructure of the town is the bed of the stream that flows linearly along the small canyon.

The "iposcafo" is the vernacular house, a cave dug into the steep sides of the valley or of the Caldera, whose outer face is walled with local stone.

The houses are usually small, consisting of two or three rooms with barrel-vaulted ceilings.

The two port villages Amoudi and Armeni are located on the slopes of the caldera, respectively, on the west and south of the castle. Significant protection works, which extend to the sea, indicate their strategic importance for the life of the territory.

The urban landscape of Oia is a wealth of high aesthetic value. The masonry elements are built with the typical red stone and black, cohesive by a mortar with high adhesion strength, rich in kaolin and lime. They extend to the outside the cave dwellings by the affixing of built elements. The adhesion of the buildings to the ground, which was manifested by the excavation before that with the built, imposes the formal reasons of a complex urban space. This is inextricably linked to the landscape and to the ground without continuity limits. The same continuity is felt between public and private space, which often coincide.

The roof of a building usually offers a terrace to the higher house, public pathways and service to homes are intertwined, and courts of buildings also act as public moments of rest during the journey of the steep paths and stairs that form the mesh of connections within the traditional settlements.

\section{INTERVENTIONS REDEVELOPMENT AND SUSTAINABILITY}

The report proposes an abstract of the degree dissertation of M Antonelli and V. Grillo, promoted as part of the workshops and training courses offered by the EU project CRIMA-CINP with the participating countries. The redevelopment of the village of Oia, was shared with the head of the technical office of Oia, Eng. Konstantinos Vafeiadis and Arch. Stella Ntakovanou.

The settlement of Oia is subject to protection restrictions. Since 1970 the organization O.N.T.H. is responsible for the conservation, restoration and enhancement of vernacular houses and buildings of historic villages. In addition, they were realized specific interventions able to restore the vitality of urban and infrastructure works that would respond to economic development and tourism in the area.
The works were financed by the public investment program of the State and with financing from the European Community. Currently the sustainability Habitat, initially supported by tourism, is likely to be compromised by his development of mass. The road infrastructures require a qualitative support to the city center and landscaping.

The project presented answers to some of the findings raised by the studies and to the demand for services and upgrading of the management program of Oia. The old and pleasant pedestrian street doesn't present public spaces staging or service, except for a small square on the side of a church in the central part of the settlement. Along the axis, there are four areas to be redeveloped, which could accommodate small public facilities, cultural, of service and commercial, integrated to spaces of collective pause along the pedestrian path, connecting elements between the two main roads and center of reference of different urban areas. The facilities, with the creation of small volumes underground and external volumes, in contrast to the logic of individualistic recently built on the island, denier of the social and community attitude of the historic architecture, offer appropriate places of pause and aggregation along the path, for residents and tourists. They safeguard the landscapes, welcome the footpath with their gardens and terraces-square, emulating the vernacular system of small meeting points traceable within the historic city, in plazas and terraces along the flanks of the caldera and often located in close proximity of churches. The structural system and constructive used for buildings proposed is the reinforced masonry with filled blocks of lapillo's stone. This native stone, light and resistant to compression, no large vacuoles, allows the hole punching of the ashlars in the factory for the production of lintels and pillars stiffening in rein-forced concrete. This system, with the armor of the horizontal joints, improve the resistance to horizontal actions, changing the behavior of natural stone, otherwise brittle, and introducing greater controllability in the behavior in the event of an earthquake.

Square with basement parking. The structure is located between the two main roads, one vehicular and the other pedestrian, and discovers the landscape of the entire island towards the caldera to the south, towards the cultivated slopes concluded from the sea to the north, and on the summit of the low hill of Mavro Vouno to the east. To the west a green shield and a masonry wall to protect the privacy of the young guests asylum. To the east, the scenic green ideally approaching the barren hill of Mavro Vouno, giving depth to the perceived landscape and hiding the structures of poor quality.

The building is proposed as an island in the ground, whose cut is exposed as a basic element for formal architectural space. The theme of the 


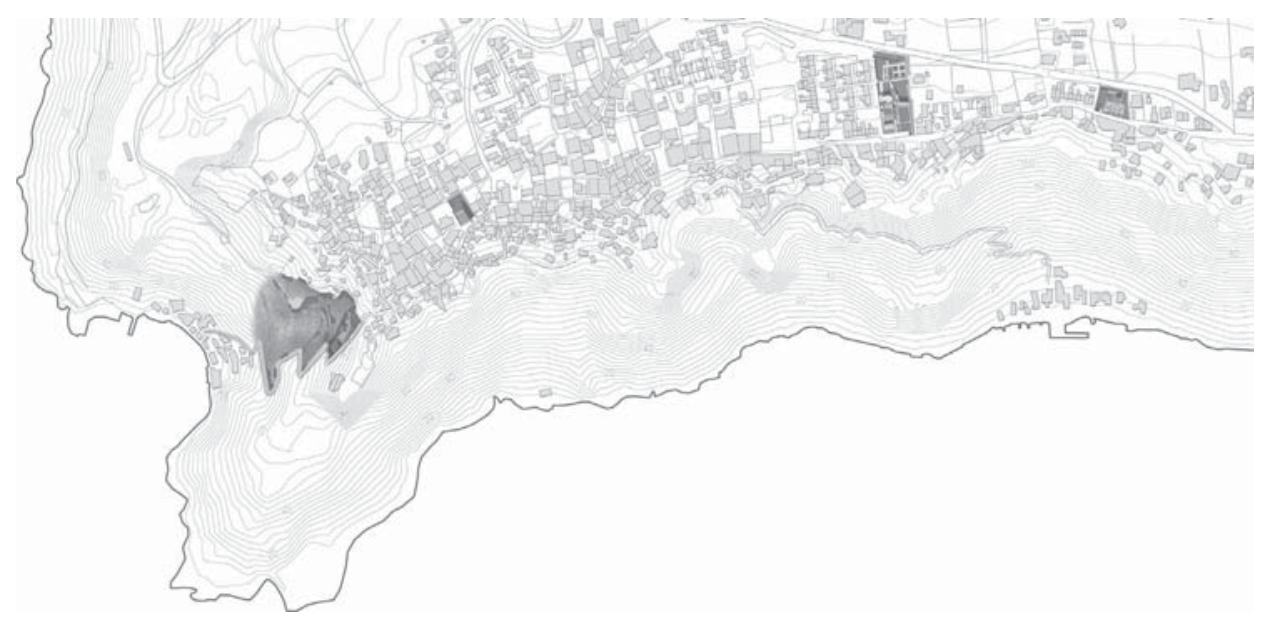

Figure 2. Localization of the four interventions within the urban fabric of Oia (Dissertations ${ }^{1}$ )

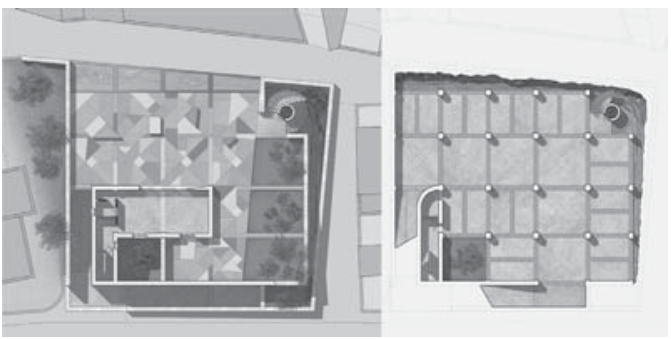

Figures 3-4. Square with basement parking: plans (Dissertations ${ }^{1}$ ).

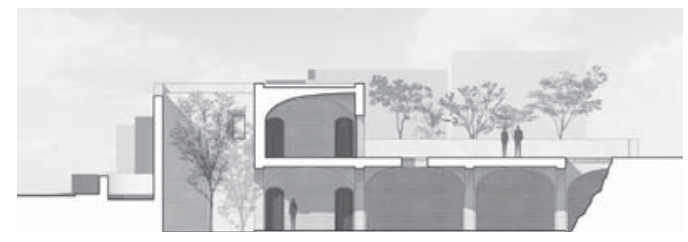

Figure 5. Square with basement parking: section (Dissertations ${ }^{1}$ ).

wall, archetype of the Mediterranean architecture, interprets the limit of the building and of the pedestrian path, with a centripetal movement open the square to the caldera, defines the entrance ramps to the parking lot, the link road and the roof garden, finally protects the square from the cold north winds, it generates a small courtyard, on which overlooks a small restaurant.

The clarity of the architectural external lines, in keeping with the traditional architecture, is in dichotomy with plastic articulation of the interior spaces, distinguished by vaulted roofs that reinterpret the enveloping character of the excavated interior of the buildings of the island.

The vault, of structural stone, is the paradigm of the identity of the place, unique way used for centuries to cover the space of life of the inhabitants of Santorini. The arches leading the vaults frame the bare rock, whose colors enhanced with oblique light, sublimate the material into semantic work of art. The natural rock interacts with the rock cut by constructing a space evocative of the relationship between the built and the natural environment.

The system Square - Cultural center. The structure is part of a modern urban context, with no for- mal figures, poor vitality and little frequented by tourists. The area to be redeveloped, which degrades from the pedestrian street to the driveway, insists the small church of St. George.

Downstream, the front of the building denounces the public and social functions and reports the accesses to the landscaped path of which, with its terraces, up-stream, is an extension. The small squares, grassed and paved, tell the colors and scents of the island, and the terraces system, valorizes the views to the sea.

The hypogea and the rupestrian buildings opening on to a central courtyard which is related with thevisual and physical crossings within the district, without a change of scale. The courtyard, dominated by the presence of pre-existing church of St. George, is the center of distribution of the building onto which faces the conference room and the space for exposures.

This is entirely articulated in negative, the external prospects with vaulted arcades blend with the internal ones, plastic and wrap, defined by the tectonics of the stone vaults. The only emerging building is the church with its bell tower and extrados 


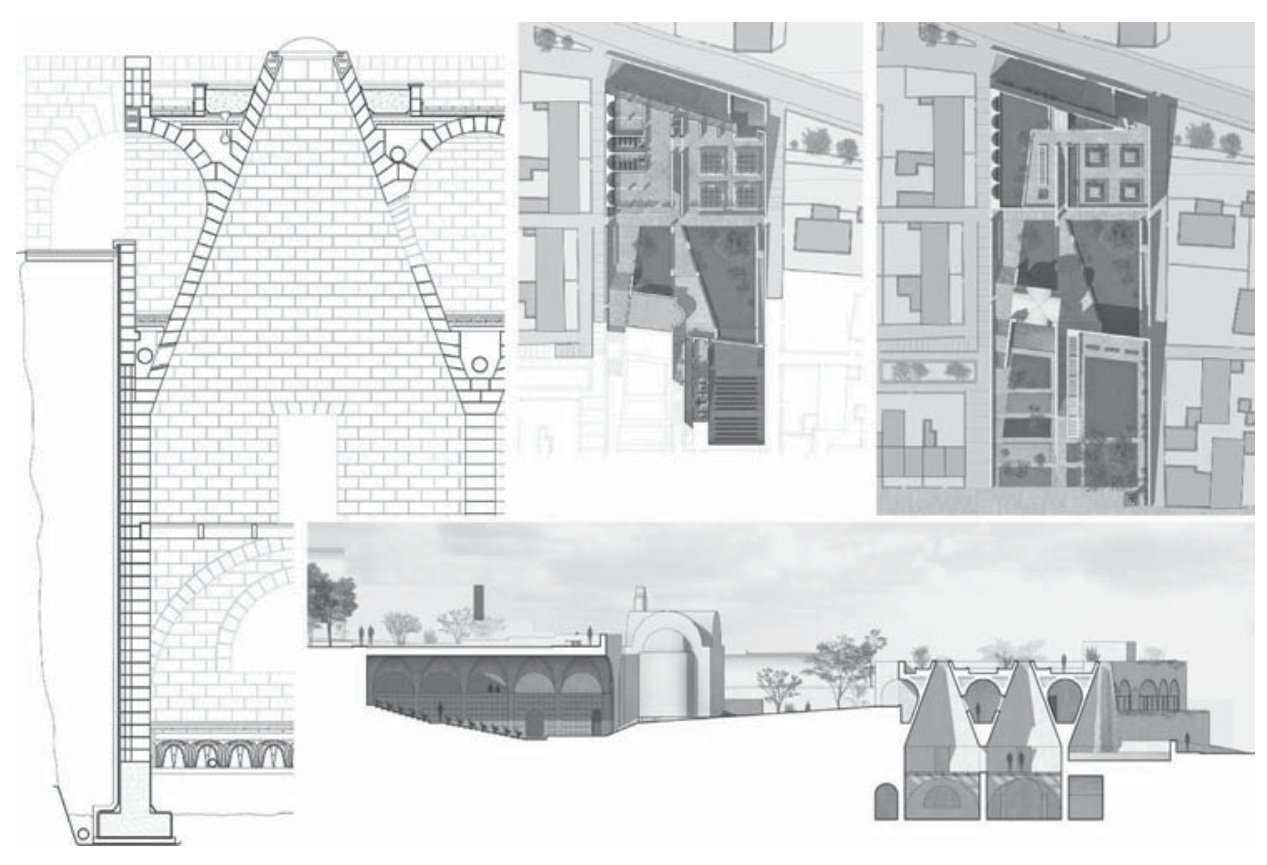

Figures 6-9. The system Square-Cultural center: ground-to-roof section; plans, longitudinal section (Dissertations ${ }^{1}$ ).

vaults, which are reflected in the pool of water at the bottom of the garden of colors.

The square in the old center. The third project involves a small space along the pedestrian street within the urban fabric of ancient foundation densely built. It is located at the junction of two ancient roads that climb in neighborhoods carved on the sides of the caldera in the west and south slopes. The area is home to an abandoned warehouse and a well dignified invoice.

Its allocation is of strategic importance for the management of the flow of tourists exploring the city as open space of safety and acceptance in the event of sudden seismic event.

The square, raised by a few steps, overlooks the caldera and offers an image of the entire island to visitors in pause. The new reception area incorporates the perimeter of the existing and, hiding the open space, surprises the visitor with the panoramic square and the Arabic garden. This emphasizes the centrality of the well restored and it is reinterpreted with the theme of the arbor, typical of Mediterranean.

This regular module define the abstract space with his mathematical grid, that became real and so dear to the inhabitants of the island.

The square theater. This intervention addresses the need for a daily mass phenomenon: the participation of tourists on the island to the event of the
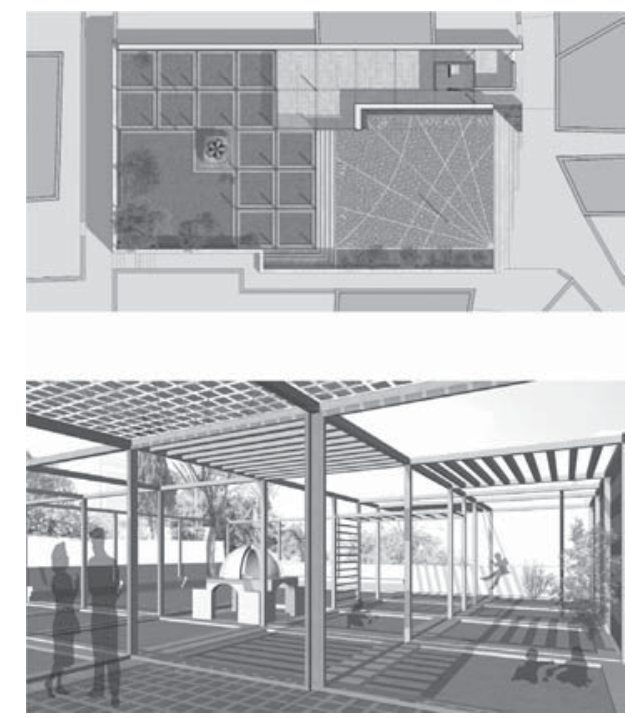

Figures 10-11. The square in the old center: plan; view of the garden (Dissertations ${ }^{1}$ ).

natural sunset. From all over the island they flock on the side west of the peninsula to participate. In fact, this show entails an urban and infrastructural burden for a few hours equal to a derby of football teams. Take the vehicular traffic access to the city is 

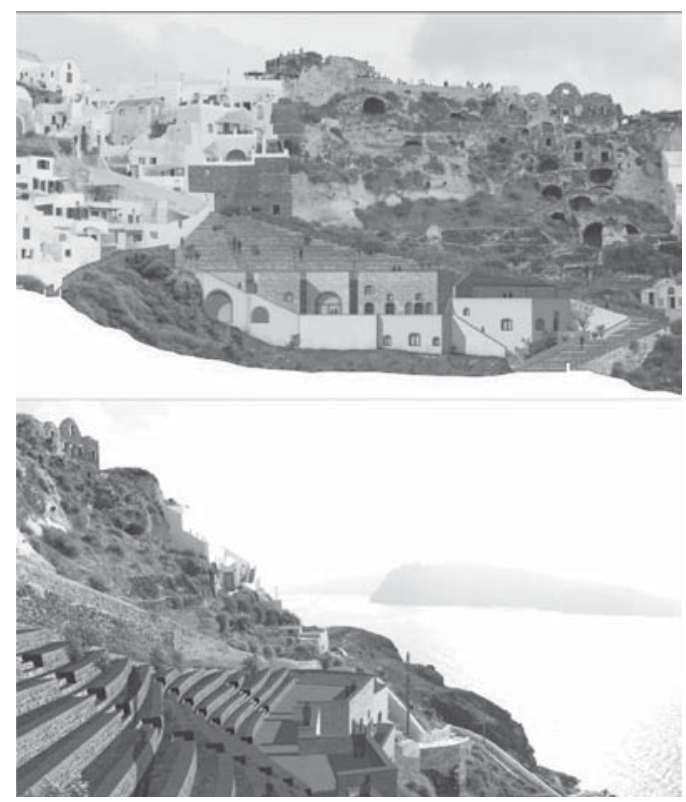

Figures 12-13. The square theater: front view of the intervention; view of the theater in the context (Dissertations ${ }^{1}$ ).

impossible and thousands of tourists dangerously flock the side-lines of alleys and small squares in the crossroads.

The project area is located at the end of the walkway of the city center, and is the culmination of more ancient route of access to the city: the wide and winding road that climbs flight of steps from the port of Amoudi, who is yet traveled on mule. The site offers a natural theater, with its views of the sea, on one of the most exciting Mediterranean landscapes. On the area of intervention, very run down, small buildings abandoned because of the earthquake of 1956, persist.

The redevelopment of the lot with the creation of footpaths connects the extreme fringes of the settlement and recovers access to a small church now abandoned. The project trails in pumice, bordered by small containment curbs stone lapilli, flank the fragments of dry stone walls remained, integrating themselves in the context and solving problems of degradation and permeability.

The restructuring and consolidation of vernacular houses built in the early twentieth requires technological solutions for the health and enjoyment of the buildings. The terraced roofs reproduce the mingling of public-private, offering themselves as squares integrated in the steep side of the caldera.
They close as cavea the flight of steps. The configuration of the square theater listen the proposals of the landscape and of human intervention retracing the sinuous lines of the ancient terraces, repopulated with new plantings of native shrubs. The intervention offers a new space to the sustainability of tourist demand and at the safety of the society and places.

\section{CONCLUSIONS}

The study activity has fostered a constructive cooperation in the definition of common ideas and strategies. The projects presented are focused on increasing the overall quality of the city, working for fragments in a few sensitive points and responding to the need for environmental and economic sustainability of the intervention. Small responses for a holistic approach to the study of the area, dealt with the entirety and complexity of its needs. A planning process that limits the depletion of the area and its attractions and environmental peculiarities giving of the possible answers to the demands of development required by the citizens. Digital models of architectures have been useful to analyze the relationship of interior spaces and the integration of volumes with outdoor spaces.

\section{REFERENCES}

AA.VV., 2012, Underground or cave structures in Greece in (edit by C. Crescenzi) The rupestrian settlements in circum mediterranean area. Unifi-DIDA, Il David, Firenze.

Crescenzi, C. 2012, Rupestrian landscape and settlements Workshops and Survey Results. Firenze: Unifi-DAdsp, Tipografia Il David, Firenze.

Crescenzi, C. 2004, La Teoria e la Pratica del taglio delle Pietre e dei Legni, per la costruzione delle volte e le parti delle costruzioni civili e Militari o Trattato di Stereotomia per l'Architettura di M.Frezier, Cavaliere dell'Ordine Militare di Saint Louis ingénieur ordinaire du roy en chef à Landau. Transltion, text and images analysis. Volumi 2. Pp.645. Firenze.

Dissertations $^{l}$, 2011/12: Scavare lo spazio, Frammenti di pietra e paesaggio per i luoghi pubblici di Oia, Santorini. Università degli Studi di Firenze. Laureandi: M. Antonelli e V. Grillo. Rel. Prof. C. Crescenzi; corr. arch. S. Ntakovanou, ing. K. Vafeiadis.

Monioudi Gavala, D. 1997, Santorini: Society and shelter 15th-20th Century, L. and E. Bellonias' Foundation, Athens.

Philippides, D. 1987, Greek traditional architecture: Santorini, Melissa, Athens.

Warlamis, E. 1995, Learning from Santorini-The ecology of the living space, World ecological school of Santorini, Santorini. 